\title{
Significance of The Regional Product Labelling for Sustainable Development in Context of Globalization
}

\author{
Pavla Varvazovska ${ }^{1, *}$, Olga Regnerova $^{2}$, Daniela Salkova ${ }^{3}$ \\ ${ }^{1}$ Czech University of Life Sciences Prague, Faculty of Economics and Management, Department of \\ Humanities, Kamycka 129, Prague 6, 165 21, Czech Republic \\ 2,3 Czech University of Life Sciences Prague, Faculty of Economics and Management, Department of \\ Trade and Finance, Kamycka 129, Prague 6, 165 21, Czech Republic
}

\begin{abstract}
Research background: Impacts of the environmental burden on our society are more and more acute. Especially in context of globalization and recent COVID-19 Pandemic, principles, instruments and forms of enviromental policies are crucial for an effective solution of the situation. It is necessary to apply these policies at local, state and global levels.

Purpose of the article: Effective communication, well aimed propaganda and relevant feed back can be considered as useful tools of action. As one of the best suitable instruments for an effective influence of citizens can be seen the use of quality labels given on the consumer products in order to support local and state economy and social integration with direct influence on territorial cohesion. In the same time, environmental education of citizens can be achieved.

Methods: Data used in this article has been gained through a questionnaire analysis, focusing on the attitudes of respondents towards quality labels and their knowledge and preferences during their shopping decisions. Quality logos shall therefore contribute to an easier orientation on the market. Rules for the coplementary logos granting must be incommutable while respecting the evidently positive impact on sustainable teritorial development.

Findings \& Value added: In context with the recent COVID-19 Pandemic, when the Czech as well as global economy will be weakend, is in the highest interest of each state to run a healthy economic strategy. And only a just support of small and middle enterprise, with a positive appeal on patriotism and sense of belonging together will play a key role. As confirmed recently, dependence on foreign imports is ineffective and undesirable, causing negative impacts on citizens lives.
\end{abstract}

Keywords: sustainable development; product label; certification; quality; consumer

JEL Classification: $R 11 ; R 58 ; Z 12$

\footnotetext{
${ }^{*}$ Corresponding author: varvazovska@pef.czu.cz
} 


\section{Introduction}

For the sustainable development of the territory in the age of globalization, it is necessary to use all areas responsibly in terms of its capacity to consume goods. This is in a way that the responsibility for the carrying capacity of the use of sub-segments will be delegated from the manufacturer to the consumer. Perceptions of product consumption must be compatible with sustainable development and the awareness of producers, transporters, traders and consumers. It must be understood as one process that must address not only the benefits but also the risks. A high probability of failure may occur if the information of all the individual components of the chain is not clear and complete. Logical interconnection is important so that responsibility for the sustainable development of the territory is delegated as a whole, which will be understandable to all act, R58ors.

Sustainable food consumption is becoming increasingly important in the face of global climate change (Brons and Oosterveer, 2017). The global food security problem has a wide range of measurements, classified by areas of origin factors, coverage of social segments of the population, geographical and others. The main goals to be achieved in ensuring the sustainable development agenda for 2030 can be defined as the quantitative increase and qualitative improvement of food products together with the expansion of access to food (Revenko et al., 2019). Regional brands can support sustainable development through positive externalities (Zhang, 2011). Regional brands contribute to sustainable development in the region in three areas: economic, environmental and social (Varvazovska and Jarkovska, 2014).

Regional brands can also help reduce the perceived risk of sustainable products (Brach et al., 2018). In this context, there is talk of the so-called regional ethnocentrism, ie. preference for consumer products (Bryla, 2019).

The aim of the article is an overview of the awarded product quality labels that are currently used in the Czech Republic and a proposal for the interconnection of these brands of individual label publishers. The work deals with finding out what meaning they have and what individual markings guarantee. The person who awards the quality marks and the conditions necessary for their acquisition, subsequent use and maintenance of the mark are identified.

The aim of the pilot survey of individual brands is to determine whether the number of currently used brands has sufficient and comprehensible informative value for consumers. This would make it easier for them to find their way when choosing quality products. The proposed solution will then strengthen the role of the coordinator of the awarded quality labels. At the same time, the coordinator should act as a single point of contact for the manufacturer interested in using the quality mark logo on his product. At the same time, also for consumers, for whom it would be easier to find more detailed information about the currently used labeling. Across all providers and control bodies, it should be possible to make more effective use of complete information, on the part of the provider, the manufacturer, but also the consumer, about the benefits of the labeling used. With uniform information, it is possible to respond more effectively to market needs, but also to solve problems associated with the sustainable development of the Czech Republic more effectively.

The Ministry of the Environment defines (MZP CR, 2021) sustainable development as a type of development which at the same time seeks to eliminate or mitigate the negative effects of the current way of development of human society. As past and present developments are based primarily on economic growth, they undoubtedly affect the shape and functioning of our planet. Most natural resources are finite and their over-exploitation damages our planet, so it could be said that they are a debt development (Rohr et al., 2021).

An important document is the Czech Republic 2030, which replaces the Strategic Framework for Sustainable Development and was adopted by the government in 2010 (Illner, 2006). The document is part of a joint effort for sustainable development of the European 
Union and at the same time also by subsidizing the Czech Republic to meet the global goals adopted by the United Nations (UN) in 2015. In the above-mentioned document, the Czech Republic committed itself, among other things, to reducing social inequalities.

The trend of moving for work to larger cities, which offer their inhabitants more efficient wage conditions and at the same time a more attractive social life, still prevails. Urban development is taking place at the expense of the countryside, and differences continue to widen (CR 2030, 2021).

The Czech Republic is characterized by a high density of settlements with a relatively even distribution, a large frequency of small rural settlements, and, conversely, a relatively small number of large cities (Illner, 2006). Through ministries, local action groups, rural support associations and other support groups, policies are developed to diversify economic activities in rural areas with a view to creating new jobs and increasing economic development. Through their activities, the institutions should contribute to a better targeting of support to the local needs of a given rural area and to the development of cooperation of actors at the local level. These activities are economically supported by a number of subsidy titles not only by the Czech Republic, but also by the European Union.

The main objectives of the programs are the restoration, preservation and improvement of ecosystems dependent on agriculture through agri-environmental measures, investment in competitiveness and innovation of agricultural enterprises, support for young people entering agriculture, landscape infrastructure, improving the quality of life of inhabitants especially in small towns and villages improving the attractiveness of municipal space.

Sustainable development indicators facilitate the evaluation of progress towards sustainability, enable comparison with recommended values, legislative limits, comparisons between states, regions, cities, and also enable the setting of development goals, evaluation of the effectiveness of funds spent. Several aspects need to be considered when choosing each indicator; the chosen methodology and the choice of data sources significantly affect the representativeness and informative value of the reliability of the evaluated results, authenticity and practical applicability (Lipovska, 2017). Akenji and Bengtsson (2014) also deals with the formulation of indicators supporting sustainable development goals. Common European Indicators or ECI (European Common Indicators) are the best known and so far the most used set of indicators of sustainable development at the local level in the Czech conditions. It was necessary to adapt the methodology to domestic conditions, individual indicators reflect the interaction between economic, social and environmental aspects (European Common Indicators, 2021).

One of the tools supported by the EU is the LEADER CR program (hereinafter Leader). Leader focuses mainly on new forms of improving the quality of life in rural areas, strengthening the economic environment and enhancing the natural and cultural heritage. This has succeeded in most countries, and the European Union has transformed the importance of Leader as a source of subsidy into a new meaning : as a method of cooperation. Unfortunately, it seems that in the Czech Republic this concept is still considered as a source of subsidies rather than as a method of territorial development, which is evidenced in particular by the rapid establishment of local action groups (LAGs).

In recent years and at present, the individual chapters of the state budget have redistributed funds to support sustainable development programs, as well as EU resources.

Below is a table of funds allocated to individual national quality labels owned by state institutions or supported by them - organic products and the volume of funds used for them have been allocated separately since 2018 . 
Table 1. National certified quality marks subsidized from the state budget of the Czech Republic

\begin{tabular}{|c|c|c|}
\hline Quality mark & Year & Allocated funds in thous. CZK \\
\hline \multirow{4}{*}{ KLASA } & 2018 & 149233 \\
\cline { 2 - 3 } & 2017 & 240302 \\
\cline { 2 - 3 } & 2016 & 131376 \\
\cline { 2 - 3 } & 2015 & 37640 \\
\cline { 2 - 3 } & 2014 & 48697 \\
\hline \multirow{4}{*}{$\begin{array}{c}\text { Regional Food } \\
\end{array}$} & 2018 & 44361 \\
\cline { 2 - 3 } & 2017 & 32424 \\
\cline { 2 - 3 } & 2016 & 30425 \\
\cline { 2 - 3 } & 2015 & 73002 \\
\cline { 2 - 3 } & 2014 & 20664 \\
\hline \multirow{4}{*}{$\begin{array}{c}\text { Organic Food and Organic } \\
\text { Products }\end{array}$} & 2018 & 1356 \\
\hline
\end{tabular}

Source: author (2021)

The individual components covering national and regional labels use very different terminology: Ministry of Agriculture lists them as quality labels, namely national quality labels (KLASA) or European quality labels (traditional specialty guaranteed), the State Agricultural Intervention Fund introduces the term national quality label and it is called regional / original / certified marks / markings, and the products obtaining this mark are certified.

Across the texts, the terms product and product and original and regional terms vary (mostly interchangeable), both within the labeling names themselves (for example, Regional Product Bohemian Paradise, Regional Product Bohemian Forest, Original Product Jeseníky, Czech Product, or even Regional Brand Vltavotýnsko), as well as in marketing texts. However, the brand name itself may not contain any of these terms (Organic Food). Christensen and O'Sullivan (2015) present a methodological approach to the study and evaluation of increasingly complex regional food systems.

For the graphic realization of the brand, the original logo is used in the Czech Republic, which can be registered at the Industrial Property Office as a trademark, but the registration itself is no guarantee of product quality - for example, over 2000 logos for bio can be found in the trademark register. According to Low and Fullerton (1994), the brand's task is to distinguish the product it represents from other goods. It connects the goods with its creator, thanks to the label the buyer knows who is behind the goods and what is its reputation. The brand therefore symbolizes the quality of goods. The brand should meet several basic criteria, the most important being memorability, meaningfulness, popularity, portability, adaptability and the possibility of protection. Blecharz (2015) characterizes quality as something that meets generally assumed criteria and that mostly or completely meets personal criteria, but all for affordable money.

\section{Methods}

For a complete overview of the usability of quality labels, a questionnaire survey was conducted, the aim of which was to examine the knowledge of individual quality labels 
(whether guaranteed or not) and the literacy of customers in this area. The questionnaire questions also focused on consumer shopping behavior and their preference when deciding between labeled products with or without a quality label. Another aim of the questionnaire survey was to find out how consumers learned about quality labels, how they assess the promotion of products marked with quality labels and whether they think that quality labels are sufficiently promoted. A total of 134 respondents participated in the questionnaire survey, of which 71 were women and 64 men. That will serve as a pilot study for a larger survey, which will also be evaluated using statistical dependencies of individual variables such as brand awareness, its quality depending on social status. The most numerous group of respondents were employed respondents, who were the target group of the questionnaire survey (115 respondents).

\section{Results and Discussions}

The initial part of the questionnaire was focused on finding out about the general awareness of the concept of quality labeling. For a more precise interpretation, the word "Czech" was used in the questions in order to clearly define the territorial perception of our state. Furthermore, questions were asked to find out whether the respondents have already encountered products marked with quality labels, to what extent they are familiar with them and whether the respondents can determine in which areas these quality labels are applied. The questionnaire also offers an overview of 11 brands with the question of whether they are certified quality marks. In conclusion, (because it can be assumed that the respondent is already familiar with the interviewed brands, even if he did not remember in the first part of the questionnaire), the personal opinion of the respondent on the quality of branded products and Czech products in general, as well as their promotion.

Table 2. Orientation of respondents in quality labels

\begin{tabular}{|l|c|c|}
\hline Selected answer & $\begin{array}{c}\text { Numer of } \\
\text { respondense }\end{array}$ & Percentage \\
\hline I never looked for it. & 51 & $38,06 \%$ \\
\hline $\begin{array}{l}\text { Yes, I can handle them more or } \\
\text { less. }\end{array}$ & 46 & $34,33 \%$ \\
\hline $\begin{array}{l}\text { I don't understand their } \\
\text { division. }\end{array}$ & 28 & $20,90 \%$ \\
\hline $\begin{array}{l}\text { Yes, I find my way around } \\
\text { them without any problems. }\end{array}$ & 6 & $4,48 \%$ \\
\hline I've never seen them. & 3 & $2,24 \%$ \\
\hline
\end{tabular}

Source: author (2021)

The data show that $38 \%$ of respondents have no awareness of quality labels, which are designed to highlight the uniqueness of products and at the same time support the development of the territory.

One of the other questions focused on the respondents' understanding of what the quality label guarantees them. Whether they are aware of the task of the marking used and in which areas it is important. Only 88 respondents $(66 \%)$ consider it a guarantee of product quality, although this is one of the main goals of the existence of labeling. 66 people (44\%) evaluate it as a guarantee of the origin of resources, which is another of the preconditions for the award of the label, 59 respondents evaluate it as a guarantee of the quality of resources and 51 people see it as a guarantee of local production. All three answers are usually common conditions for obtaining labeling. It is therefore a question why there is a lack of trust on the 
part of consumers - whether it is due to personal experience, insufficient advertising of labels or products or ignorance of the added value (local sustainable development, employment, development of rural areas) of labeling in this area. A total of 58 respondents (of which only 17 for small businesses) see the labeling as a function to support local economies and small businesses, for which regional brands in particular are intended. Only 23 respondents see the guarantee of special technological procedures in marking. These data suggest that there is a need to increase general knowledge of the benefits to local sustainable development of using and purchasing products with quality labels.

The most widespread quality brand on our market is clearly KLASA, which is the most preferred among respondents. Of the 134 respondents, 118 people $(88 \%)$ correctly described it as a quality mark, and of these respondents, almost $80 \%$ consider the mark as a guarantee of quality. This brand is also one of the brands that is heavily subsidized from the state budget. The Regional Food quality label, which is also promoted from the Czech budget, is also doing very well. It was marked as a quality mark by 78 respondents $(58 \%), 37$ respondents $(28 \%)$ do not know or cannot answer with certainty, 19 people think that this mark is not a certified quality mark. The Regional Food brand introduces consumers to award-winning regional foods and at the same time supports small and medium-sized producers in the regions.

The Regional Food brand goes through various competitions, which help to make visible the products marked with this logo. Of the respondents who know it as a quality label, 69 know that the label can be obtained by agricultural products and 60 respondents are familiar with the designation of labels for regional products. 9 out of 15 respondents who chose "regional exhibitions" as an area with the possibility of obtaining labels, know Regional Food. It follows that the link between the 'Regional Food' brand and the regional origin of the product is not as clear as the name suggests, or is misleading.

The EU logo for organic quality was answered in question number 11 in the questionnaire. While the Czech logo for organic food was answered only in question number 19, although logos are usually displayed on all Czech products at the same time. The purpose of this division was to find out whether consumers can combine these brands as one piece of information, which is displayed together in retail outlets. The European organic food logo shows that $54 \%$ of respondents do not know that this image is a quality mark, another $13 \%$ of respondents stated that this mark is not a quality mark. Only less than a third of respondents know that the logo is a quality brand. This may be due to the absence of text on the logo, or its presentation together with more prominent Czech markings, the so-called "zebra". The "biozebra" quality label is known to respondents from $66 \%$, although it is a label that can only be found on products that meet strict legislative requirements. Therefore, the explanation is correct that the conditions for organic products are met only by products marked with the Czech and EU logos. At the same time, information about organic products is unnecessarily confusing in the red heart. Consumers may then mistakenly consider this marking to be a guarantee of quality. Almost a third of respondents do not trust the quality label. It is therefore argued that labeling has no weight for respondents to convince consumers that they will get a quality product for their money thanks to quality labels. The most effective way for respondents to learn about quality labels is to portray them on the product (Lorenz el al., 2015). Thus, promotion in this way appears to be effective. However, customers should rather be convinced that the quality mark shown on the product should buy the product precisely because of this marking because of its quality guarantee, which is shown on the packaging. In addition to state quality labels, which are financed from the budget of ministries, there are a number of quality labels on the market, backed by non-profit companies, firms or interest groups. They usually finance the promotion of brands from membership fees or license fees, in the past often from EU subsidies. Most brands on the market target the patriotic feeling of consumers by depictions in the colors of the national flag (Morley and Morgan, 2021), or 
mark products from Czech raw materials, or even products where the share of Czech work is guaranteed. Furthermore, labeling often relies on a healthy lifestyle.

\section{Conclusion}

An inexhaustible amount of quality labels, together with other logos displayed on the products, causes chaos and devalues the original good idea. That aimed to distinguish quality Czech products that support the sustainable development of municipalities, cities and the entire Czech Republic. With this amount of quality labeling, both manufacturers and consumers are unable to determine whether quality labels guarantee them anything. The funds that are supposed to promote quality labeling are spent unnecessarily on most promotional activities, as the desired effect of supporting the Czech economy is not proportional to their amount. It is necessary to grasp the original good idea and start building on it again, with new and clear rules. But this time with the lesson that too many quality labels lose their exclusivity of exceptionality.

As part of the promotion of Czech products that demonstrably support the sustainable development of the territory, a single coordination center could be set up.

Another function of the coordination center, in cooperation with other institutions, must be to educate the population in spreading information: what is and what is the importance of sustainable development of the territory. Only mutual cooperation and the willingness of all involved can ensure effective results.

Following the current coronavirus pandemic, which is weakening not only the Czech but also the world economy, it is in the best interest of any country to start a sound economic strategy. And it is the support of small and medium-sized enterprises, with a positive appeal to patriotism and belonging, that will play a key role. As has already been confirmed, dependence on imports from abroad is often inefficient and undesirable in the context of globalization, with negative effects on the population of the state.

\section{Acknowledgements}

The information introduced in this paper resulted from the solution of a project of Internal Grant Agency (IGA) No. 20151051, Faculty of Economics and Management Czech University of Life Sciences Prague "Civic activism and its projection into the local political life."

The authors of the paper wish to thank Mrs.Volfová for making their contact with state institutionand non-profit organizations possible.

\section{References}

1. Akenji, L., \& Bengtsson, M. (2014). Making sustainable consumption and production the core of sustainable development goals. Sustainability, 6(2), 513-529.

2. Blecharz, P. (2015). Kvalita a zákaznik. Ekopress.

3. Brach, S., Walsh, G., \& Shaw, D. (2018). Sustainable consumption and third-party certification labels: Consumers' perceptions and reactions. European Management Journal, 36(2), 254-265.

4. Brons, A., \& Oosterveer, P. (2017). Making sense of sustainability: A practice theories approach to buying food. Sustainability, 9(3), 467.

5. Bryla, P. (2019). Regional ethnocentrism on the food market as a pattern of sustainable consumption. Sustainability, 11(22), 6408. 
6. CR 2030, (2021, Septemper 08). ČR společně-udržitelně. http://cr2030.cz.

7. European Common Indicators (2021, Septemper 08). Společné evropské indikátory. https://ci2.co.cz/cs/spolecne-evropske-indikatory-eci

8. Christensen, L. O., \& O'Sullivan, R. (2015). Using social networking analysis to measure changes in regional food systems collaboration: A methodological framework. Journal of Agriculture, Food Systems, and Community Development, 5(3), 113-129.

9. Illner, M. (2006). Jsou venkovské obce př́liš malé ? In Venkov je náš svět - Sborník z konference 2006. Česká zemědělská univerzita, 2006. pp. 357-367. Retrieved from: http://soclab.pef.czu.cz/pdf/Sbornik_Venkov_neprodejne.pdf

10. Lipovska, H. (2017). Moderní ekonomie : jednoduše o všem, co byste měli vědět. Grada.

11. Lorenz, B. A., Hartmann, M., \& Simons, J. (2015). Impacts from region-of-origin labeling on consumer product perception and purchasing intention-Causal relationships in a TPB based model. Food quality and preference, 45, 149-157.

12. Low, G. S., \& Fullerton, R. A. (1994). Brands, brand management, and the brand manager system: A critical-historical evaluation. Journal of marketing research, 31(2), 173-190.

13. Morley, A., \& Morgan, K. (2021). Municipal foodscapes : Urban food policy and the new municipalism. Food Policy, 103, 102069.

14. MZP CR, (2021, Septemper 08). Udržitelný rozvoj. https://www.mzp.cz/cz/ udrzitelny rozvoj

15. Revenko, L.,Panteleeva, O., \& Isachenko, T. (2019). European Regional Food Security Policy Regulation. Contemporary Europe-Sovremennaya Evropa, (2),129-141.

16. Rohr, V., Blakley, J., \& Loring, P. (2021). A framework to assess food security in regional strategic environmental assessment. Environmental Impact Assessment Review, 91, 106674.

17. Varvazovska, P., \& Jarkovska, M. (2014). Regional food as expression of identity and sustainability in regional development. Marketing Identity: Explosion of Innovations, 512-523, ISBN 978-80-8105-666-6.

18. Zhang, R. B. (2011). Externality of Regional Brands and Corporate Social Responsibility. In Proceedings of the 7th Euro-Asia Conference on Environment and CSR: Technological Innovation and Management Science Session (pp. 238-244). 